\title{
SOSIALISASI DAN PELATIHAN PENGGUNAAN MESIN PEMIPIL JAGUNG PORTABLE DI DESA BOTUWOMBATO, KECAMATAN KWANDANG, KABUPATEN GORONTALO UTARA
}

\section{Socialization and Training of Portable Corn Thrasher Machine in Botuwombato Village, Kwandang District, North Gorontalo}

Agus Susanto Ginting ${ }^{1)}$, Moh.Fikri Pomalingo ${ }^{2)}$, Sjahril Botutihe ${ }^{3)}$, Romi Djafar ${ }^{4)}$, Siradjuddin Haluti ${ }^{5)}$

${ }^{1,2,3,4,5)}$ Staf Pengajar Program Studi Mesin dan Peralatan Pertanian Politeknik Gorontalo

J1. Muchlis Rahim Desa Panggulo, Kec. Botupingge Kab. Bone Bolango, Provinsi Gorontalo Email: agus.ginting@poligon.ac.id

\begin{abstract}
ABSTRAK
Jagung merupakan komoditi utama di Provinsi Gorontalo khususnya di Kabupaten Gorontalo utara dengan produksi jagung sekitar 50 ribu ton/tahun. Salah satu wilayah penyumbang produksi jagung di kabupaten ini adalah Desa Botuwombato dengan Luas tanaman jagung di desa ini mencapai 550 ha dengan hasil panen mencapai 4.950 ton/tahun. Jagung biasanya ditanam diareal perbukitan dengan kondisi lahan miring. Permasalahan yang dihadapai adalah besarnya biaya yang gunakan pada saat panen untuk mentransportasikan jagung dari lahan ke wilyah pemukiman. Tujuan pengabdian ini adalah untuk melakukan sosialisasi dan pelatihan penggunaan mesin pemipil portable sehingga proses pemipilan dapat dilakukan di lahan pertanaman
\end{abstract}

Kata Kunci lahan miring, jagung, pemipil portable

\section{ABSTRACT}

Corn is the main commodity in Gorontalo Province, especially in North Gorontalo Regency with corn production of around 50 thousand tons / year. Botuwombato Village is one of contributor in corn production in this district with corn plant area in this village reaching 550 ha with yields reaching 4,950 tons / year. Corn is usually planted in the hillsides with sloping land conditions. The problem faced is the amount of costs used at harvest to transport corn from land to residential areas. The purpose of this service is to conduct socialization and training in the use of portable thrasher machines. Piping process can be carried out in the planting area

Key words Sloping Land,corn, Portable Thrasher 


\section{PENDAHULUAN}

Jagung merupakan komoditas utama provinsi Gorontalo. Tanaman ini menjadi penyumbang pendapatan daerah terbesar dari sektor pertanian sejak provinsi ini dibentuk pada tahun 2001. Berdasarkan laporan dari Dinas Pertanian, Tanaman Pangan dan Hortikultura Provinsi Gorontalo tahun 2015, luas panen tanaman jagung sekitar 129.131 ha dengan produksi mencapai 643.512 ton. Salah satu kabupaten yang memproduksi jagung terbesar adalah kabupaten Gorontalo Utara. Berdasarakan data dari BPS Gorontalo tahun 2017, Luas panen di kabupaten Gorontalo Utara mencapai 12.845 ha, dengan hasil panen mencapai 55.306 ton.

Topografi lahan di provinsi Gorontalo yang berbukit-bukit menjadi salah satu faktor sulitnya mendapatkan lahan datar untuk membudidayakan jagung. Untuk meningkatkan hasil tanaman jagung, maka petani membudidayakan jagung di daerah perbukitan. Hasil panen jagung di lahan miring biasanya mencapai sekitar 5-6 ton/ha. Pertanian di lahan perbukitan biasanya berjarak 5-7 km dari pemukiman warga, dengan medan yang berat, karena harus menyusuri lembah, sungai dan bukit.

Jagung yang ditanam pada lahan miring hasilnya lebih sedikit dibandingkan lahan datar, namun karena ketersediaan lahan yang luas, dan lahan tersebut hanya cocok untuk tanaman jagung, maka petani berupaya untuk membudidayakannya. Rerata luas lahan yang digarap oleh petani berkisar antara 1,2-2 ha, akan tetapi ada beberapa petani yang menggarap 20-40 ha. Petani tersebut biasanya sudah merangkap sebagai pengumpul (tengkulak). Pada umumnya penanaman jagung pada lahan perbukitan dapat tumbuh dengan baik, namun salah satu masalah yang dihadapi oleh petani adalah pada saat panen. Biaya terbesar pada saat panen adalah pengangkutan jagung dari kebun hingga ke perkampungan. Pengangkutan jagung dilakukan dengan menggunakan sepeda motor. Jagung yang diangkut kondisinya belum terpipil dan biayanya berkisar $\mathrm{Rp}$ 5.000 - Rp 10.000/karung tergantung jarak pengangkutan. Karung yang digunakan adalah karung beras ukuran $50 \mathrm{~kg}$. Pengangkutan jagung yang belum dipipil, disebabkan sulitnya membawa pemipil jagung ke kebun karena dimensinya yang besar dan jaraknya yang jauh. Sementara itu, jika pemipilan dilakukan secara manual, pemilik kebun membutuhkan tenaga, waktu dan biaya yang banyak.

Berdasarkan uraian tersebut, salah satu solusi terbaik yang harus dilakukan untuk mengurangi biaya transportasi adalah mengangkut jagung dari kebun ke perkampungan dalam kondisi sudah terpipil. Untuk melakukan pemipilan di kebun, diperlukan sebuah inovasi baru, berupa pemipil jagung yang portable, mudah dioperasikan, murah dan tepat guna bagi petani sehingga dapat meningkatkan pendapatan petani.

Desa Botuwombato merupakan salah satu desa yang terletak di Kecamatan Kwandang Kabupaten Gorontalo Utara. Desa ini merupakan salah satu penghasil jagung. Kontur perkebunan jagung di desa ini berbukit. Salah satu kendala yang dihadapai petani adalah pada saat panen untuk itu akan dilaksanakan pengabdian berupa sosialisasi dan pelatihan penggunan mesin pemipil portable untuk memipil jagung dilahan perbukitan.

\section{SOLUSI, TARGET LUARAN DAN CAPAIAN}

\section{Solusi}

Solusi yang ditawarkan dari program ini :

1. Pemanfaatan mesin kenderaan bermotor roda dua sebagai sumber penggerak sekaligus pembawa mesin pemipil jagung 
2. Pemipilan jagung dapat dilakukan diareal pemanenan jagung yang ada diperbukitan

3. Bobot jagung yang ditransportasikan menjadi lebih ringan karena hanya biji jagung yang dibawa sedangkan tongkolnya ditinggalkan di lahan pertanaman

4. Petani dapat mengoprasikan mesin pemipil jagung Portable dengan baik

\section{Target luaran}

Luaran yang diharapakan dari kegitatan ini antara lain :

1. Mesin pemipil portable dapat diterapkan sebagai pemipil jagung dilahan perbukitan

2. Modul/buku saku cara pengoprasian mesin pemipil portable yang mencakup, a) pengenalan alat, $b$ ) bagian-bagian alat, c) fungsi dan kegunaan alat, d) keunggulan alat, dan e) tata cara penggunaan alat

3. Publikasi media masa dan juga publikasi ilmiah

\section{Capaian}

Capaian yang diharapakan dalam pelaksanaan kegiatan pengabdian ini adalah :

1. Menumbuh kembangkan pemahaman masyarakat tentang kemajuan taknologi pertanian

2. Mengurangi biaya transportasi jagung dari lahan pertanian

3. Membangun kemitraan antara masyarakat dan perguruan tinggi dalam pengembangan mesin pemipil

\section{MOTODE PELAKSANAAN}

Pengabdian ini bersifat terapan, dimana masyarakat diharapkan mampu menggunakan atau menguasai tatacara penggunaan mesin pemipil jagung portable. Adapun metode pengabdian yang dilakukan berdasarakan diagram alir yang ditunjukkan pada gambar 1 berikut ini

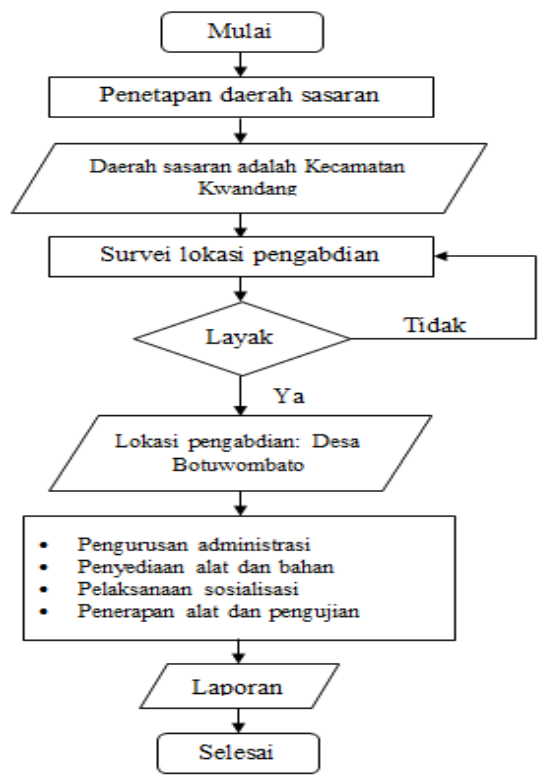

Gambar 1 diagram alir pengabdian kepada masyarakat

\section{Alat dan Bahan}

Pelaksanaan pengabdian ini dilakukan dalam dua tahap, yakni pelaksanaan sosialisasi dan pengujian alat. Adapun alat dan bahan yang digunakan antara lain:

a. Pelaksanaan sosialisasi, alat dan bahan yang digunakan adalah Mesin Pemipil Potable, Kenderaan bermotor roda dua, spanduk, dan buku panduang penggunaan Mesin Pemipil Portable

b. Pengujian, alat dan bahan yang digunakan adalah Mesin Pemipil dan jagung yang sudah dipanen yang sudah tekupas dari kulitnya.

\section{Cara Kerja Mesin}

Sebelum mesin pemipil digunakan, yang diperhatikan terlebih dahulu adalah pengguna harus mengetahui bagian-bagian dari alat, sebagaimana dijelaskan pada 
buku panduan. Penggunaan mesin pemipil , yaitu:

- Pemasangan poros pada mesin motor roda dua

- Pemasangan Pulley pada poros

- Menghubungkan V-belt pada Pulley yang terletak pada poros motor dengan Pulley yang terletak pada pemipil

- Menghidupkan motor penggerak dan mengatur kecepatan motor yang direduksi pada putaran pemipil

- Melakukan proses pemipilan pada mesin

Sumber tenaga penggerak untuk proses pemipilan berasal dari mesin sepeda motor yang juga berfungsi sebagai sarana pengangkut mesin ke lahan pertanaman jagung. Gambar 2 berikut menunjukkan pengandengan mesin pemipil pada sepeda motor

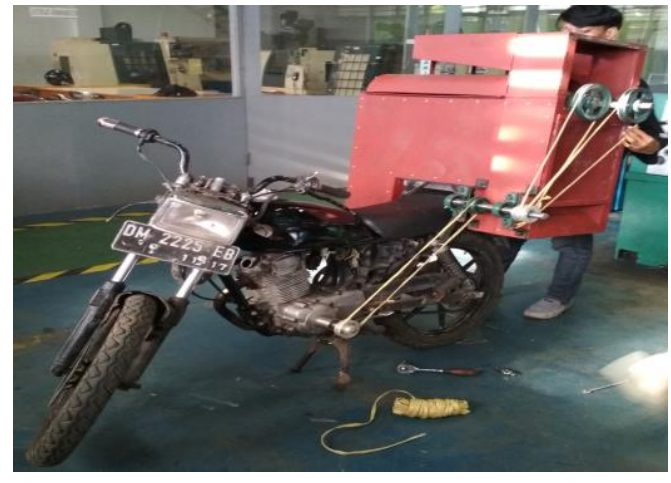

Gambar 2 penggandengan mesin pada sepeda motor

\section{Persiapan Pengabdian}

Kegiatan ini dimaksudkan untuk mengetahui sejauh mana persiapan pelaksanaan kegiatan akan dilakukan. Kegiatan ini mencakup penyediaan alat dan bahan yang dibutuhkan dalam pelaksanaan kegiatan pengabdian. Indikator utama dalam kegiatan ini adalah menyediakan alat dan bahan/materi sosialisasi serta leaflet dan buku panduan penggunaan mesin pemipil portable.

\section{HASIL DAN PEMBAHASAN}

\section{Peninjauan Lokasi}

Peninjauan lokasi dimaksudkan untuk mengetahui kelayakan lokasi yang akan digunakan sebagai sasaran pengabdian. Lokasi ini dapat dibagi dalam dua kategori. Kategori pertama adalah lokasi pelaksanaan sosialisasi dan kategori kedua adalah lokasi tempat dimana mesin pemipil digunakan. Berdasarkan survei yang dilakukan, lokasi yang menjadi sasaran baik pelaksanaan sosialisasi maupun pengujian alat yaitu Desa Botuwombato, Kec. Kwandang, Kab. Gorontalo Utara. Kelayakan dan penetapan tersebut didasarkan pada beberapa alasan mendasar, diantaranya:

a) Desa Botuwomato merupakan wilayah yang sebagian besar penduduknya adalah petani, terutama petani jagung.

b) Daerah pertanaman sebagaian besar dialukan diperbukitan.

\section{Hasil pengamatan kondisi desa}

Desa Botuwombato merupakan salah satu desa di Kecamatan Kwandang, Kabupaten Gorontalo Utara, Provinsi Gorontalo desa ini merupakan pemekaran dari desa Molingkapoto. Jumlah penduduk dari desa ini sebanyak 2.200 jiwa yang terdiri dari 200 kepala keluarga. Luas wilayah desa ini kurang lebih 2.000 ha. Topografi wilayah berbukit-bukit, sehingga tanaman yang banyak dibudidayakan di daerah ini adalah jagung. Sebagian besar jagung di daerah ini di tanam pada lahan miring.

Luas tanaman jagung di desa ini mencapai 550 ha dengan hasil panen mencapai 4.950 ton/tahun. Penanaman jagung berlangsung dua kali setiap tahun, dengan produksi jagung mencapai 7-9 ton/ha. Kondisi Lahan dan peta wilayah 
desa ditunjukkan pada gambar 3 berikut ini.
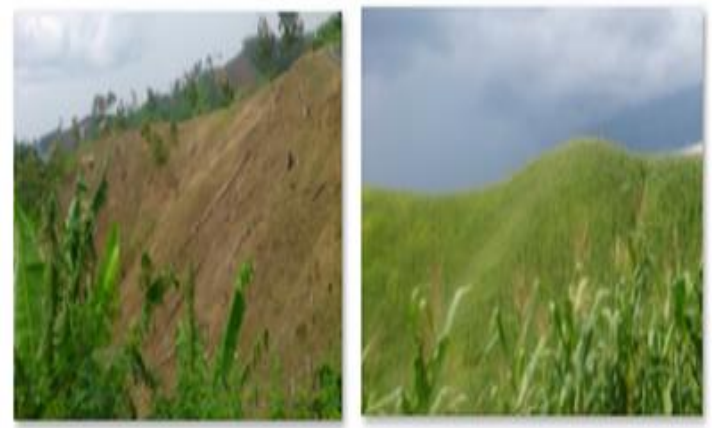

(a)

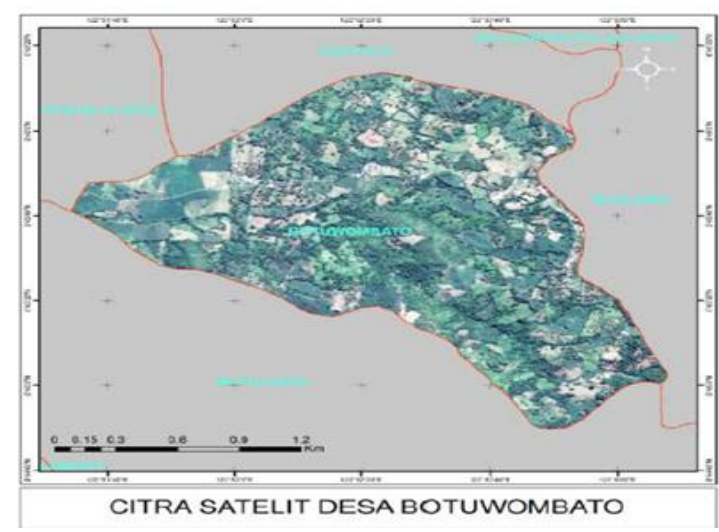

(b)

Gambar 3 (a) Kondisi lahan kemiringan lahan pertanaman jagung, (b) Peta wilayah Desa Botuwombato

\section{Pengujian proses pemipilan jagung}

Proses uji coba mesin dilakuan di kantor desa Botuwombato bersama denga aparatur dan warga desa. Gambar 4 menunjukkan kegiatan tersebut

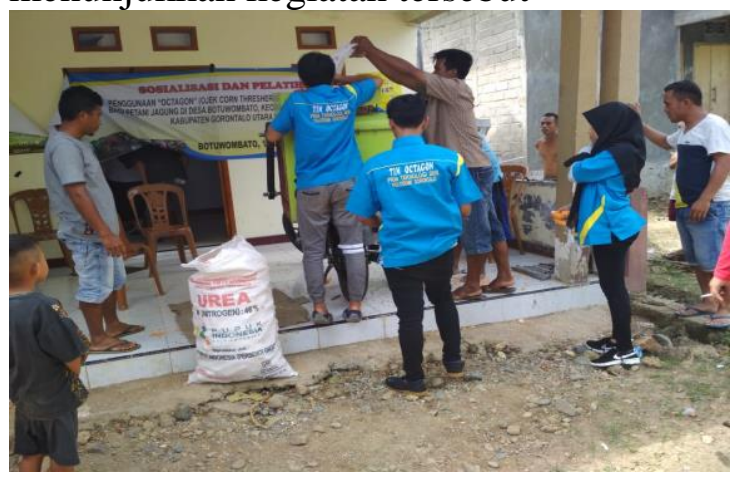

Gambar 4 Proses pemipilan
Proses pemipilan dimulai dengan memasukkan buah jagung melalui saluran pemasukan yang dilanjutkan ketahap pemipilan pada ruang pemipil. Mekanisme pemipilan terjadi dengan cara buah jagung akan memasuki celah yang terdapat pada dua poros pemipil yang berputar berlawanan arah. Poros pemipil yang dilengkapi dengan besi beton yang dililitkan menyerupai ulir pada poros akan memberikan gaya gesek yang memisahkan biji jagung dari tongkolnya. Biji jagung akan melewati kisi-kisi dibawah poros pemipil untuk teruskan ke saluran pengeluaran biji. Tongkol jagung dengan mekanisme screw conveyor yang terdapat pada poros pemipil akan membawa tongkol ke saluran pengeluran tongkol pada sisi yang berbeda dari saluran pengeluaran biji.

Permasalahan yang dihadapi pada proses pemipilan ini adalah masih ditemukannya jagung yang belum terpipil secara sempurna dan masih adanya biji jagung yang keluar dari saluran pengeluaran tongkol. Hal ini disebabkan oleh jarak ulir pada poros pemipil yang masih besar dan kecepatan putaran poros pemipil yang cukup tinggi yang menghasilkan momentum yang cukup besar dalam mengarahkan biji jagung ke saluran pengeluaran biji dan tongkol.

\section{KESIMPULAN DAN SARAN}

\section{Kesimpulan}

Berdasarakan kegiatan pengabdian yang dilakukan dapat disimpulkan :

1. Desa Botuwombato merupakan salah satu wilayah yang mempunyai potensi produksi jagung yang besar.

2. Sebagian besar lahan pertanaman jagung dilakukan dilahan miring

3. Mesin pemipil jagung portable dapat diaplikasikan sebagai solusi 
untuk memipil jagung di daerah perbukitan

\section{Saran}

Perlu perbaikan khususnya pada komponen pemipil dan mekanisme pemipilan sehingga jagung dapat dipipil dengan sempurna

\section{UCAPAN TERIMA KASIH}

Ucapan terima kasih disampaikan kepada Yayasan Pengembangan Sumber Daya Manusia (YPPSDM) Gorontalo dan Direktur Politeknik Gorontalo yang telah mendanai kegiatan ini dalam hibah dana Pengabdian Kepada Masyarakat Tahun 2018.

\section{DAFTAR PUSTAKA}

Laporan Akhir Tahun Dinas Pertanian, Tanaman Pangan dan Hortikultura Provinsi Gorontalo, 2015

Badan Pusat Statistik Provinsi Gorontalo.

Luas Panen dan Produksi

Tanaman Pengan Menurut

Kabpaten/Kota, 2015 